\title{
PENERAPAN KONSELING INDIVIDU DENGAN TEKNIK INSTRUKSI DIRI DALAM PENDEKATAN TERAPI KOGNITIF- PERILAKU UNTUK MENGURANGI KEJENUHAN PADA MAHASISWA \\ (Penelitian Subjek Tunggal Terhadap Mahasiswa Fakultas Ilmu Pendidikan Universitas Negeri Jakarta)
}

\author{
Usnaziqyah Raqfika ${ }^{1}$ \\ Awaluddin Tjalla ${ }^{2}$ \\ Indira Chanum ${ }^{3}$
}

\begin{abstract}
Abstrak
Artikel ini bertujuan untuk mengetahui pengaruh penerapan teknik instruksi diri dalam pendekatan terapi kognitif-perilaku untuk mengurangi kejenuhan pada mahasiswa yang memiliki kejenuhan tinggi dalam menjalani rutinitas perkuliahan. Penelitian ini dilaksanakan di Fakultas Ilmu Pendidikan Universitas Negeri Jakarta, dengan satu responden yaitu mahasiswa berinisial AWU yang merupakan mahasiswa dari jurusan Bimbingan dan Konseling angkatan 2013. Responden diambil dengan pertimbangan dan tujuan tertentu. Penelitian ini adalah Penelitian Subjek Tunggal dengan menggunakan desain A-B, dimana A adalah kondisi baseline yang belum diberikan intervensi dan B adalah kondisi intervensi dengan teknik Instruksi Diri yang diberikan kepada AWU yang mengalami kejenuhan tinggi pada dirinya. Layanan yang diberikan adalah layanan responsif yaitu konseling individu yang terdiri 3 fase, yaitu; (1) konseptualisasi masalah yang dihadapi oleh konseli, (2) melakukan teknik instruksi diri, (3) mengevaluasi proses konseling dan mengakhiri konseling. Hasil penelitian keseluruhan menunjukkan adanya penurunan tingkat kejenuhan konseli pada setiap dimensi kejenuhan yaitu dimensi kelelahan, sinisme dan ketidakberhasilan dengan penerapan teknik Instruksi Diri dalam waktu 10 kali penerapan pada kondisi intervensi. Teknik ini dapat dilaksanakan dengan baik oleh konseli karena dengan senang hati konseli melakukannya tanpa paksaan dari pihak manapun.
\end{abstract}

Kata Kunci : teknik instruksi diri, kejenuhan

\section{PENDAHULUAN}

Dalam rangka mengembangkan potensi peserta didik secara optimal maka diselenggarakannya serangkaian kegiatan pembelajaran yang bersifat formal, nonformal maupun informal dengan berbagai jenjang. Salah satu jenjang pendidikan formal adalah pendidikan tinggi. Menurut UU No. 12 Tahun 2012 tentang Pendidikan Tinggi, "mahasiswa adalah peserta didik pada jenjang pendidikan tinggi". Kehidupan mahasiswa berkaitan dengan tugas perkuliahan yang diberikan dosen untuk pemenuhan masa perkuliahan. Bagi setiap mahasiswa mencapai keberhasilan berprestasi dalam kegiatan perkuliahan adalah hal yang penting, namun setiap mahasiswa memiliki kemampuan yang berbeda-beda dan memiliki beban tugas yang sama. Tugastugas perkuliahan tersebut menjadi tuntutan yang harus dikerjakan.

\footnotetext{
${ }^{1}$ Mahasiswa Program Studi Bimbingan dan Konseling FIP UNJ, usnaziqyah@gmail.com

${ }^{2}$ Dosen Program Studi Bimbingan dan Konseling FIP UNJ, awaluddin.tjalla@gmail.com

${ }^{3}$ Dosen Program Studi Bimbingan dan Konseling FIP UNJ, indirasunito@yahoo.com
} 
Berdasakan Buku Pedoman Akademik Universitas Negeri Jakarta tahun 2011/2012, selain tugas perkuliahan tersebut, mereka wajib menyelesaikan beban studi 144 SKS, menyelesaikan beban studi per semester disesuaikan dengan IPS (Indeks Prestasi Semester) yang diperoleh, kegiatan tatap muka, kehadiran mahasiswa minimal $80 \%$ dari masa perkuliahan, ujian tengah semester dan ujian akhir semester, mengikuti praktik keterampilan mengajar dan penyusunan skripsi hingga selesai.

Ketidaksesuaian antara kemampuan individu dengan tuntutan dalam perkuliahan tersebut dapat membuat individu merasa tidak mampu dan lelah untuk menjalaninya. Hal ini dapat membuat individu merasa jenuh dalam menjalani rutinitas perkuliahannya. Mahasiswa yang memiliki daya juang tinggi akan mampu mengatasi rasa jenuh yang dialaminya, sedangkan mahasiswa yang memiliki tingkat kejenuhan tinggi dan tidak dapat mengatasinya sendiri akan berdampak buruk bagi pencapaian prestasi dan masa studinya.

Kejenuhan adalah sindrom psikologis ditandai dengan kelelahan, sinisme dan ketidakberhasilan (Maslach \& Leiter, 1997). Fenomena yang terjadi di Fakultas Ilmu Pendidikan angkatan 2013/2014 terdapat $0,52 \%$ yang memiliki IPK $\leq 2,5$ (Tata Usaha Fakultas Ilmu Pendidikan, 2015). Hasil studi pendahuluan yang dilakukan pada mahasiswa Fakultas Ilmu Pendidikan mengenai kejenuhan adalah mahasiswa cukup merasa terbebani dengan tuntutan-tuntutan perkuliahan seperti tugas perkuliahan dengan tenggang waktu yang singkat untuk menyelesaikan tugas tersebut, kegiatan praktikum yang cukup menguras waktu dan tenaga, kemudian merasa sangat kelelahan dengan tuntutan tersebut baik secara fisik maupun emosional dan merasa jenuh dalam menjalani rutinitas perkuliahan.

Berdasarkan hasil studi pendahuluan dan fenomena yang terjadi di Fakultas Ilmu Pendidikan, memungkinkan salah satu penyebab mahasiswa tidak berhasil dalam pencapaian prestasi adalah kejenuhan yang dialaminya. Terdapat 6 (enam) orang mahasiswa Fakultas Ilmu Pendidikan yang memiliki kejenuhan tinggi yaitu dari jurusan Bimbingan dan Konseling sebanyak 1 (orang) dan jurusan Psikologi sebanyak 5 (lima) orang dengan IPK rata-rata $\leq 2,5$.

Untuk membantu mengurangi kejenuhan pada mahasiswa dapat dilakukan melalui layanan bimbingan dan konseling yaitu dengan pendekatan konseling. Salah satu teori atau pendekatan yang dianggap sesuai untuk mengurangi kejenuhan adalah Pendekatan Terapi Kognitif-Perilaku dengan teknik Instruksi Diri. Menurut Meichenbaum (dalam Sharf, 2004) teknik instruksi diri adalah cara untuk individu mengajarkan pada diri mereka sendiri menangani secara efektif terhadap situasi yang sulit bagi diri individu tersebut.

Berdasarkan pemaparan di atas, maka penulis tertarik untuk melakukan penelitian tentang "penerapan konseling individu dengan teknik instruksi diri dalam pendekatan terapi kognitif-perilaku untuk mengurangi kejenuhan pada mahasiswa terutama mahasiswa yang memiliki Indeks Prestasi $\leq 2,5$ dan mengalami tingkat kejenuhan yang tinggi”.

\section{KAJIAN TEORI KEJENUHAN}

Menurut Maslach \& Leiter (1997) kejenuhan adalah sindrom psikologis ditandai dengan kelelahan, sinisme dan ketidakberhasilan. Kejenuhan juga dipengaruhi oleh ketidaksesuaian antara kemampuan yang dimiliki oleh mahasiswa dengan tuntutan dalam perkuliahan yang harus dikerjakan. Jacob \& Dodd (2003) mengatakan bahwa kejenuhan yang dialami mahasiswa membuat suasana di dalam kegiatan perkuliahan menjadi tidak menyenangkan, dedikasi dan komitmen menjadi berkurang serta rendahnya pencapaian prestasi individu.

Kejenuhan yang dialami mahasiswa adalah sindrom psikologis yang disebabkan adanya rasa kelelahan yang luar biasa baik secara fisik maupun emosional 
akibat dari tuntutan dalam perkuliahan yang menyebabkan mahasiswa bersikap sinis terhadap dirinya dan orang lain serta mengurangi keterlibatan diri dalam melakukan aktivitas perkuliahan bahkan menganggap dirinya tidak kompeten sebagai mahasiswa sehingga terjadi penurunan pencapaian prestasi pribadi. Leiter \& Maslach (1997) menyebutkan ada tiga dimensi dari burnout, yaitu:

1. Kelelahan (Exhaustion)

Kelelahan merupakan dimensi kejenuhan yang ditandai oleh perasaan letih berkepanjangan baik secara fisik maupun emosional. Ketika individu mengalami kelelahan, individu akan merasa semua energinya telah terkuras, terpakai sampai habis, tidak dapat beristirahat dan tidak dapat memulihkannya kembali atau bersemangat. Individu yang mengalami kelelahan ketika bangun di pagi hari, individu akan tetap merasa lelah. Individu merasa kekurangan energi untuk menghadapi kegiatan sepanjang hari. Perasaan atau respons ini adalah hal yang akan dirasakan pertama kali oleh individu ketika mengalami kelelahan luar biasa dalam suatu aktivitas. Kelelahan pada mahasiswa ditandai dengan perasaan sangat letih baik secara fisik maupun emosional akibat tuntutan dalam perkuliahan.

2. Sinisme (Cynicism)

Sinisme merupakan dimensi kedua kejenuhan, ketika individu merasakan dimensi kedua ini, individu akan bersikap sinis terhadap orang-orang yang berada dalam lingkungannya dan memberikan jarak serta mengurangi keterlibatan diri dalam melakukan aktivitas bahkan menyerah terhadap cita-cita. Sikap sinisme sendiri adalah sebagai upaya untuk melindungi diri individu untuk menghindari perasaan kecewa setelah mengalami kelelahan. Sinisme pada mahasiswa ditandai dengan sikap sinis terhadap orang lain di dalam lingkungannya, enggan untuk terlibat dalam kegiatan kuliah seperti mengerjakan tugas-tugas kuliah baik individu maupun kelompok serta individu mudah putus asa.

3. Ketidakberhasilan (Ineffectiveness)

Ketidakberhasilan merupakan dimensi kejenuhan yang ditandai dengan perasaan tidak berdaya, tidak mampu melakukan tugas, menganggap tugas yang diberikan berat. Ketika individu mulai merasakan ketidakberhasilan, individu mulai merasakan tidak mampu dalam menyelesaikan tugas tertentu. Individu juga merasakan kehilangan kepercayaan terhadap kemampuannya dan karena mereka kehilangan kepercayaan diri mereka sendiri membuat orang lain kehilangan kepercayaan terhadap dirinya sehingga timbul perasaan tidak berguna. Ketidakberhasilan yang terjadi pada mahasiswa ditandai dengan perasaan tidak mampu untuk menyelesaikan tugas kuliah dan menganggap bahwa tugas yang diberikan akan dirasakan sangat berlebihan serta membuat individu merasa tidak berguna sebagai seorang mahasiswa.

TEKNIK INSTRUKSI DIRI (SELF INSTRUCTION) DALAM TERAPI KOGNITIF-PERILAKU

Teknik instruksi diri adalah bagian dari pendekatan Terapi Kognitif-Perilaku. Bush (2003) mengungkapkan bahwa Terapi Kognitif-Perilaku, merupakan perpaduan dari dua pendekatan dalam psikoterapi, yaitu terapi kognitif dan terapi perilaku. Terapi kognitif memfokuskan pada pikiran, asumsi dan kepercayaan serta memfasilitasi individu belajar mengenali dan mengubah kesalahan sedangkan terapi tingkah laku membantu hubungan antara situasi permasalahan dengan kebiasaan mereaksi (merespons) permasalahan. Individu belajar mengubah perilaku, menenangkan pikiran dan tubuh sehingga merasa lebih baik, berpikir lebih jelas dan membantu membuat keputusan yang tepat.

Terapi ini memadukan pendekatan kognitif dan perilaku untuk memecahkan 
masalah. Salah satu teknik dalam Terapi Kognitif-Perilaku yang digunakan untuk memodifikasi dan merestrukturisasi sistem kognisi adalah teknik instruksi diri (Meichenbaum, 1979). Teknik instruksi diri untuk mengendalikan pikiran negatif dengan terus menerus melakukan verbalisasi diri secara positif yang merupakan strategi pemecahan masalah yang akan diajarkan kepada individu sebagai salah satu upaya untuk menurunkan tingkat kejenuhannya.

Menurut Safaria (2004) teknik instruksi diri merupakan teknik yang menggunakan instruksi-diri berupa kalimat pernyataan positif ketika berhadapan dengan permasalahan dalam suatu situasi tertentu di lingkungan kehidupannya.

\section{METODE PENELITIAN}

Tujuan penelitian ini adalah untuk mengetahui pengaruh konseling individu dengan menggunakan teknik instruksi diri dalam pendekatan terapi kognitif-perilaku untuk mengurangi kejenuhan pada mahasiswa Fakultas Ilmu Pendidikan Universitas Negeri Jakarta. Penelitian ini dilakukan sejak bulan Oktober 2014 - November 2015. Dilakukan empat belas kali pertemuan kegiatan konseling individu dengan pemberian baseline (A) dan intervensi (B).

Kegiatan dilakukan di gedung Daksinapati lantai 2 yaitu Di Lab. Konseling. Metode yang digunakan dalam penelitian adalah Single Subject Research (SSR), dengan desain A-B.

Teknik yang digunakan dalam penelitian adalah purposive sampling karena hanya mahasiswa yang memiliki kejenuhan tinggi yang menjadi subjek penelitian. Subjek penelitian berinisial AWU sesuai dengan kriteria penelitian yaitu memiliki tingkat kejenuhan tinggi sebesar 68 dan dengan IPK dari semester 1 sampai semester 4 sebesar 2.09. Penelitian menggunakan instrumen adaptasi MBISS (Maslach Burnout Inventory Student Survey). Instrumen ini dikembangkan oleh Wilmar B. Schaufeli dan Marisa Salanova yang berasal dari teori burnout Maslach yang terdiri dari 15 butir pernyataan, reliabilitas instrumen ini adalah 0.852 yang berarti mempunyai hubungan yang erat (reliable). Peneliti melakukan uji coba instrumen pada 60 responden yaitu mahasiswa yang memiliki IP $\leq 2.5$ didapat semua item valid, sedangkan berdasarkan rumus alpha cronbach didapat nilai reliabilitas sebesar 0.848 .

Menurut Arikunto (2010:319) nilai reliabilitas sebesar 0.848 bermakna reliabel, artinya instrumen MBISS reliabel dan layak digunakan sebagai alat ukur dalam penelitian. Berdasarkan pemaparan dalam latar belakang masalah, maka peneliti menganggap penting untuk melakukan penelitian tentang penerapan teknik instruksi diri dalam pendekatan terapi kognitif-perilaku untuk mengurangi kejenuhan mahasiswa Program Studi Bimbingan dan Konseling Fakultas Ilmu Pendidikan Universitas Negeri Jakarta.

\section{HASIL DAN PEMBAHASAN}

Penelitian dilakukan sebanyak empat belas kali pertemuan. Pertemuan pertama sampai dengan pertemuan keempat, peneliti melakukan baseline (A) untuk memperoleh data skor awal kejenuhan sebelum diberikan intervensi. Pada pertemuan kelima peneliti mulai melakukan intervensi (B) karena kondisi baseline sudah stabil. Menurut Juang (2005:94) keadaan data stabil pada kondisi baseline secara meyakinkan bahwa intervensi perlu segera diberikan.

Proses konseling dilakukan dengan melakukan asesmen yang sebelumnya telah dikumpulkan oleh peneliti yaitu instrumen adaptasi MBISS untuk mengukur tingkat kejenuhan AWU, angket untuk studi pendahuluan mengenai kejenuhan yang dialami AWU, wawancara tidak terstruktur untuk memperoleh data mengenai masalah yang dihadapi konseli dengan menelaah emosi/perasaan dan situasi AWU terkait dengan kejenuhan yang dialaminya dan studi dokumentasi untuk mengetahui IPK (Indeks Prestasi Kumulatif) dan KHS (Kartu Hasil Studi) AWU pada semester 1-4.

Hasil awal instrumen adaptasi MBISS 
AWU yaitu sebesar 68 terdapat pada kategori sangat tinggi. Hal ini didukung dari hasil angket studi pendahuluan dan wawancara bahwa AWU memang jenuh terhadap rutinitas perkuliahannya serta hasil studi dokumentasi berupa IPK pada semester 1 sampai semester 4 sebesar 2.09 yang merupakan kategori rendah $\leq 2.5$. Hasil asesmen menunjukkan bahwa AWU termasuk kategori mahasiswa yang mengalami kejenuhan tinggi dan memerlukan tindakan konseling individu untuk menurunkan kejenuhannya.

Keseluruhan melakukan konseling dalam kondisi intervensi sebanyak 10 kali pertemuan dengan rincian sebagai berikut; (1) konseptualisasi masalah sebanyak tiga sesi, (2) Implementasi teknik instruksi diri sebanyak enam sesi, dan (3) mengevaluasi proses konseling dan mengakhiri konseling satu sesi.

Berikut adalah tabel penurunan skor kejenuhan AWU:

Tabel 1

Skor Kejenuhan AWU

\begin{tabular}{ccc}
\hline Sesi & Tanggal & Skor kejenuhan \\
\hline 1 & 5 Oktober 2015 & 68 \\
2 & 12 Oktober 2015 & 67 \\
3 & 19 Oktober 2015 & 66 \\
4 & 26 Oktober 2015 & 64 \\
5 & 30 Oktober 2015 & 61 \\
6 & 2 November 2015 & 57 \\
7 & 6 November 2015 & 54 \\
8 & 9 November 2015 & 52 \\
9 & 13 November 2015 & 51 \\
10 & 16 November 2015 & 46 \\
11 & 20 November 2015 & 46 \\
12 & 23 November 2015 & 44 \\
13 & 27 November 2015 & 37 \\
14 & 30 November 2015 & 29 \\
\hline
\end{tabular}

Tabel di atas menunjukkan bahwa skor kejenuhan AWU mengalami penurunan dari sebesar 68 yaitu pada kategori tinggi dan menjadi sebesar 29 pada kategori sedang.

Data pada tabel di atas dapat digambarkan pada grafik sebagai berikut:
Grafik 1

Kejenuhan AWU

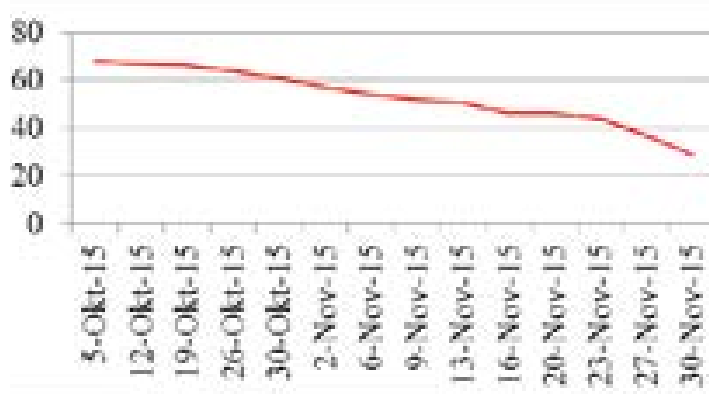

Grafik di atas dapat dilihat bahwa garis grafik menurun yang bermakna kejenuhan AWU mengalami penurunan.

Berdasarkan pengamatan yang dilakukan peneliti selama 9 minggu diperoleh sebuah kesimpulan bahwateknik Instruksi Diri dapat diterapkan kepada AWU yang memiliki kejenuhan tinggi. Hal ini berbanding lurus dengan hasil penelitian tentang kejenuhan yang sudah dilakukan terlebih dahulu oleh para peneliti sebelumnya bahwa penerapan teknik instruksi diri dapat mengurangi kejenuhan yaitu hasil penelitian yang dilakukan oleh Sugara (2011) menunjukkan bahwa teknik instruksi diri efektif dalam menurunkan kejenuhan pada siswa Sekolah Menengah Atas. Hasil penelitian lain yang mendukung adalah penelitian yang dilakukan oleh Firmansyah (2012). Hasil penelitiannya senada dengan peneliti sebelumnya yaitu teknik instruksi diri efektif digunakan dalam mereduksi kejenuhan pada siswa Sekolah Menengah Pertama.

Hasil penelitian peneliti juga menghasilkan kesimpulan yang sama dengan dua peneliti sebelumnya, namun peneliti mengambil ranah yang berbeda yaitu dalam setting Pendidikan Tinggi dengan subjek penelitian mahasiswa. Dari pemaparan di atas dapat dimaknai bahwa teknik instruksi diri dapat mengurangi kejenuhan yang dialami siswa pada jenjang pendidikan Sekolah Menengah Pertama (SMP) dan Sekolah Menengah Atas (SMA) serta hasil penelitian peneliti teknik instruksi diri dapat dilakukan pada mahasiswa pada jenjang pendidikan Perguruan Tinggi (PT) untuk mengurangi kejenuhan yang dialami mahasiwa. Hal 
ini dibuktikan dengan adanya penurunan skor kejenuhan mahasiswa antara kondisi baseline dan kondisi intervensi. Martin, dkk. (2007) mengungkapkan bahwa prosedur teknik instruksi diri dapat diadaptasi untuk menangani masalah orang dewasa dengan beragam masalah, salah satunya kejenuhan.

Menurut Meichenbaum (dalam Sharf, 2004) teknik instruksi diri adalah cara untuk individu mengajarkan pada diri mereka sendiri menangani secara efektif terhadap situasi yang sulit bagi diri individu tersebut. Bryan dan Butt (1982) menambahkan teknik instruksi diri merupakan teknik yang cocok untuk menangani masalah emosional dan perilaku. Kejenuhan yang dialami mahasiswa berkaitan dengan emosi dan perilaku. Individu yang merasa kejenuhan dalam menjalani perkuliahannya akan merasakan emosi-emosi negatif pada dirinya seperti tertekan, gelisah, frustasi, murung, putus asa, tidak bergairah, pesimis, takut dan sebagainya. Emosi-emosi ini yang membuat individu menampilkan perilaku yang maladaptif terhadap perkuliahan, misalnya malas mengerjakan tugas kuliah, tidak masuk kegiatan tatap muka di kelas perkuliahan, tidak antusias dalam kegiatan perkuliahan, tidak mau terlibat dalam lingkungan perkuliahan dan sebagainya. Hal ini menunjukkan bahwa teknik instruksi diri dapat digunakan untuk mengurangi kejenuhan yang dialami mahasiswa.

Kegunaan teknik instruksi diri dijelaskan oleh Friedenberg \& Gilis (dalam Lange, 1998) yaitu untuk mengganti pemikiran negatif menjadi positif, didasari oleh pemikiran bahwa pandangan seseorang mengenai dirinya dapat diarahkan. Sementara itu, kegunaan lain dari teknik ini adalah untuk mengarahkan perilaku didasari oleh pemikiran bahwa pemberian instruksi merupakan bagian penting pada perkembangan manusia dalam mengarahkan perilaku (Rock, 1997). Sesuai dengan teori dan beberapa hasil penelitian relevan tentang teknik instruksi diri dapat menurunkan kejenuhan maka hasil dari penelitian ini juga demikian bahwa teknik instruksi diri dapat mengurangi kejenuhan pada mahasiswa. Hasil perhitungan skor kejenuhan sebelum diberikan intervensi dengan menggunakan teknik instruksi diri yaitu skor kejenuhan konseli berjumlah 66,25 berada pada kategori tinggi dan setelah diberikan intervensi terdapat penurunan skor menjadi 47,7 berada pada kategori sedang.

Dalam hal ini konseli yang mengalami kejenuhan dan ditangani dengan teknik instruksi diri dapat mengurangi kejenuhannya dengan baik dengan cara mengganti pemikiran negatif otomatis yang muncul karena emosi negatif konseli menjadi pemikiran yang positif terlebih dahulu. Pemikiran negatif otomatis konseli yang mengalami kejenuhan seperti "saya merasa tidak mampu dalam mengikuti kelas perkuliahan" diubah menjadi "saya akui mengikuti kelas perkuliahan tidak mudah, tapi saya yakin bisa mengikuti kelas perkuliahan dengan baik", dan sebagainya. Pernyataan tersebut diinstruksikan pada diri individu sendiri secara berulang-ulang sampai konseli yakin untuk menampilkan perilaku sesuai dengan pemikiran positifnya.

\section{KESIMPULAN DAN SARAN}

Setelah semua tahap dalam penelitian dilakukan, dapat disimpulkan bahwa kejenuhan AWU menurun. Hasil perhitungan skor kejenuhan sebelum diberikan intervensi dengan menggunakan teknik instruksi diri yaitu skor kejenuhan AWU berjumlah 66.25 berada pada kategori tinggi dan setelah diberikan intervensi terdapat penurunan skor kejenuhan menjadi 47.7 berada pada kategori sedang.

Saran-saran yang dapat menjadi pertimbangan dalam penelitian ini sebagai berikut:

\section{Bagi AWU}

Hasil penerapan teknik instruksi diri dalam pendekatan terapi kognitifperilaku diharapkan dapat menetap pada diri konseli.

2. Bagi Calon Konselor

Menggunakan teknik instruksi diri untuk 
mengurangi individu yang memiliki kejenuhan tinggi dan mengetahui dimensi-dimensi yang ada dalam kejenuhan.

3. Bagi UPT-LBK Program intervensi dapat direkomendasikan kepada pihak UPT LBK sebagai salah satu referensi untuk melakukan kegiatan konseling individu pada mahasiswa yang memiliki kejenuhan tinggi.

4. Bagi Program Studi Bimbingan dan Konseling

Hasil penelitian dapat menjadi salah satu sumber data mahasiswa jurusan Bimbingan dan Konseling yang membutuhkan tindak lanjut dari Program studi Bimbingan dan Konseling terkait dengan kejenuhan yang dialami mahasiswanya.

5. Bagi peneliti selanjutnya

Hasil penelitian dapat digunakan sebagai rujukan penelitian relevan.

a. Instrumen MBISS dapat digunakan untuk mengukur kejenuhan dan mengetahui apakah teknik instruksi diri berpengaruh positif dalam penurunan kejenuhan.

b. Membuat desain penelitian subjek tunggal selain desain $A-B$, seperti desain A-B-A dan A-B-A-B.

\section{DAFTAR PUSTAKA}

Arikunto, S. (2010). Manajemen Pendidikan. Jakarta: Rineka Cipta.

Bush, J.W. (2003). Cognitive Behavioral Therapy: The Basic.

Galbraith, C.S., \& Merrill, G.B. (2014). Academic performance and burnout: an efficient frontier analysis of resource use efficiency among employed university students. Journal of Further and Higher Education, 39(2), 255-277.

Firmansyah, R. (2012). Efektivitas Teknik Self Instruction untuk Mereduksi Gejala Kejenuhan Belajar Siswa. Skripsi Jurusan Psikologi Pendidikan dan Bimbingan UPI.
Maslach, C., \& Leiter, M.P. (1997). The Truth About Burnout: How Organizations Cause Personal Stress and What to Do About it. San Francisco: Jossey-Bass Publishers.

Meichenbaum, D. (1977). CognitiveBehavior Modification: An Integratif Appoarch. New York: Plenum Press.

Safaria, T. (2004). Terapi Kognitif Perilaku Untuk Anak. Yogyakarta: Graha Ilmu.

Sugara, G.S. (2011). Efektivitas Teknik Self Instruction dalam Menangani Kejenuhan Belajar Siswa. Skripsi Jurusan Psikologi Pendidikan dan Bimbingan UPI.

Sunanto, J. (2005). Pengantar Penelitian dengan Subyek Tunggal. CRICED University of Tsukuba. 
